\title{
Influence of nitrogen and mineral fertilizer application rates for legumes on the number of stems and the amount of NPK in the soil
}

\author{
Abduvali Iminov ${ }^{1, *}$, Furkatbek Achilov ${ }^{1}$, Akhmad Kurbonov ${ }^{1}$, and Dilnoza Usmonova ${ }^{2}$ \\ ${ }^{1}$ Tashkent State Agrarian University, Universitetskaya str., 2, 100140, Tashkent
}

\begin{abstract}
Inoculation of seeds of legumes (soybean - Glycine max L., mung bean - Phaseolus aureus L., wild beans - Phaseolus) grown as a secondary crop after winter wheat before sowing with nitragin and application of mineral fertilizers in different doses affected the amount of endogenous bacteria formed in the plant root as well as the agrochemical properties of the soil. Inoculation of legume seeds with nitragin before sowing and application of mineral fertilizers at different rates increased the amount of humus in the topsoil $(0-30 \mathrm{~cm})$ layer by $0.025-0.029 \%$ compared to the initial values, and the total nitrogen content by $0.009-0.012 \%$. The formation of endogenous bacteria in the root of the plant was inoculated with nitrogen before sowing the seeds of soybean, moss, bean crops. The amount of legumes was 22.7-36.7 pieces in the variant, in which the mineral fertilizers $\mathrm{N}_{30} \mathrm{R}_{90} \mathrm{~K}_{60} \mathrm{~kg} / \mathrm{ha}$ was applied, whereas it was $12.0-15.6$ pieces in the variant without any mineral fertilizers.
\end{abstract}

\section{Introduction}

Among the agricultural crops on earth, legumes and legumes have their own characteristics. Only legumes and legumes accumulate natural biological nitrogen in the soil in a symbiosis with nitrogen-fixing bacteria, forming a tuber at the root $[1,2,7]$. The activity and activity of endogenous bacteria that live in the roots of legumes and assimilate free nitrogen in the air is closely related to the life of the host plant. depends on the designation. The activity and activity of depleted bacteria, which live in the roots of leguminous cereals and absorb nitrogen in the air freely, is closely related to the life of the boss plant [11, 13]. Their activity depends on how much care the crops are taken, timely conduct of agrotechnical activities, in particular, on the correct definition of the norms of their nutrition due to soilclimatic conditions [3, 6-8]. Usually physiologically active substances are formed by means of leguminous cereals, which improve the nitrogen assimilation of the finished bacteria in the root. Part of this assimilated nitrogen is necessary for the life of the plant in the future

* Corresponding author: iminov1977@mail.ru 
and positively affects its growth, development [1, 4-6]. Numerous studies showed that legumes absorb free nitrogen from the air by endogenous root bacteria and were associated with the effects of agronomic practices in their care. Accordingly, biological, physiological and biochemical bases of assimilation of free nitrogen in the air by endogenous bacteria living in the roots of legumes were developed $[1,3,6]$. The use of nitrogen in combination with mineral fertilizers, that is, $\mathrm{P}_{90} \mathrm{~K}_{60}+$ nitrogen and $\mathrm{N}_{30} \mathrm{P}_{90} \mathrm{~K}_{60}+$ nitrogen variants, ensures the formation of the highest number of endogenous bacteria. An increase for nitrogen leads to a decrease in the formation of endogenous bacteria and no formation at all $[7,12]$.

Studies have shown that by studying the role of biological and mineral nitrogen, it has scientifically and practically substantiated that biological nitrogen is a nitrogen-biological nitrogen accumulated by endogenous bacteria live in the roots of legumes and absorb nitrogen from the air. It is noted that the mechanism and weight of free nitrogen in the air by the bacteria living in the roots of legumes depends on the species, varieties, natural climatic conditions and cultivation techniques, in particular the timing and norms of cultivation [10]. Once the bacteria enter the roots of legumes, they undergo a series of changes, first into a rod-shaped form, then forming bacteroides, which absorb free nitrogen from the air and begin to accumulate in the roots of legumes [8]. It was found that increasing the dose of mineral fertilizers in backgrounds inoculated with nitrogen before sowing the seeds of bean crops grown as a secondary crop led to an increase in the amount of ammonifiers, oligonitrophils, micromycetes and actinomycetes compared to the control option [4].

\section{Materials and methods}

The research was conducted in 2015-2017 in the conditions of typical gray soils of Tashkent region. Before sowing soybean seeds as a repeat crop Bradyrhizobium japonicum SB5, moss seeds Phaseolus radiatus 148, bean seeds Rhizobium phacelia 143 strains inoculated and non-inoculated backgrounds without mineral fertilizers following $\mathrm{R}_{90} \mathrm{~K}_{60}$, $\mathrm{N}_{60}, \mathrm{~N}_{90}, \mathrm{~N}_{60}, \mathrm{~N}_{30} \mathrm{R}_{90} \mathrm{~K}_{60} \mathrm{~kg} /$ ha were tested. The experiment included 24 options, each with an area of $240 \mathrm{~m}^{2}$, of which $120 \mathrm{~m}^{2}$ were taken into account [3-5, 7]. It was conducted in three iterations and the total area of the experiment was $17280 \mathrm{~m}^{2}$. In the experiment, earlymaturing soy varieties "Dream", "Pobeda-104" and "Golden Hair" beans were planted in the first ten days of July. Soybeans were planted at a rate of $60 \mathrm{~kg}$ per hectare, moss $16 \mathrm{~kg}$, beans $100 \mathrm{~kg}$, at a depth of 4-5 cm. Upon completion of planting, seed water was given in order to obtain full seedlings. The research was conducted in the field and in the laboratory, where the placement of field experiments, calculations and observations were carried out based on "Methods of field experiments", soil and plant analysis "Methods of agrochemical analysis of soil and plants" [2-5]. Mineral fertilizers for crop care: ammonium nitrate (N 33-34\%), amorphous (N 11-12\%, $\mathrm{R}_{2} \mathrm{O}_{5}-46 \%$ ), superfos (N-5-6\%, $\mathrm{R}_{2} \mathrm{O}_{5}-32 \%$ ), potassium chloride $\left(\mathrm{K}_{2} \mathrm{O}-60 \%\right)$ was applied.

\section{Results and discussion}

It was found that inoculation with nitrogen before sowing the seeds of legumes grown as a secondary crop and the application of mineral fertilizers in different doses affected the number of endogenous bacteria formed in the roots of plants. The results showed that the amount of endogenous bacteria formed in the roots of soybean (Glycine max L.) crop grown as a repeat crop during the lactation period of plants was 4.7-14.8 units/plant. The highest rates of endogenous bacteria formed in the roots of soybeans grown as a secondary 
crop after winter wheat were observed in the variant 7, accounted for 14.8 units/plant, where the norm of mineral fertilizers $\mathrm{N}_{30} \mathrm{R}_{90} \mathrm{~K}_{60} \mathrm{~kg} / \mathrm{ha}$ was applied against the background of inoculation with nitrogen before sowing the seeds of this crop. In the variant 2, the norm of $\mathrm{N}_{30} \mathrm{R}_{90} \mathrm{~K}_{60} \mathrm{~kg} / \mathrm{ha}$ of background mineral fertilizers sown without inoculation with nitrogen before sowing soybean seeds was 6.2 units/plant. It was observed that sowing of soybean seeds, which were grown as a secondary crop after winter wheat, by inoculation with nitrogen before sowing, had an effect on increasing the amount of endogenous bacteria formed in the plant root.

It was found that the amount of endogenous bacteria formed in the root of the mung bean (Phaseolus aureus L.) crop grown as a secondary crop after winter wheat was 11.421.2 units/plant. The highest rates of endogenous bacteria formed in the roots of moss were observed in the variant 15, where the norm of mineral fertilizers $N_{30} R_{90} K_{60} \mathrm{~kg} /$ ha was used in the background inoculated with nitrogen before sowing the seeds of this crop was 21.2 units/plant. In the 10th variant, where the norm of mineral fertilizers $N_{30} R_{90} K_{60} \mathrm{~kg} / \mathrm{ha}$ was applied in the background without inoculation with nitrogen before sowing the seeds of mung bean, the total amount of bacteria formed in the root of the plant was 14.3 units/plant. The sowing of moss seeds, which were grown as a secondary crop after winter wheat, by inoculation with nitrogen before sowing also had an effect on the increase for bacteria formed in the root of the plant.

It was found that the amount of endogenous bacteria formed in the root of the wild beans (Phaseolus) crop grown as a secondary crop was 3.2-13.0 units/plant. The highest rates of endogenous bacteria formed in the root of the wild beans crop were observed in the variant 23, where the norm of $\mathrm{N}_{30} \mathrm{R}_{90} \mathrm{~K}_{60} \mathrm{~kg} / \mathrm{ha}$ of mineral fertilizers inoculated with nitrogen before sowing the seeds of this crop was 13.0 units/plant. It was observed that the legumes grown as a secondary crop entered the flowering phase and an increase for bacteria formed in the roots of the plants. The amount of total bacteria formed in the roots of soybeans grown as a secondary crop was 7.1-18.9 units/plant, in the case of mung bean, it was18.6-30.0 unit/plant, and in wild beans, it was 6.3-17.8 units/plant.

The highest values of the number of endogenous bacteria formed in the roots of the plant in the flowering phase of moss grown as a secondary crop were observed in variant 15 , where the norm of mineral fertilizers inoculated with nitrogen $N_{30} R_{90} K_{60} \mathrm{~kg} / \mathrm{ha}$, before sowing the seeds of this crop were 30.0 units/plant. The highest rates of the number of endogenous bacteria formed in the root of the plant during the flowering phase of beans were observed in the variant 23 , where the norm of $\mathrm{N}_{30} \mathrm{R}_{90} \mathrm{~K}_{60} \mathrm{~kg} / \mathrm{ha}$ of mineral fertilizers inoculated with nitrogen before sowing the seeds of this crop was 17.8 / plant. As the legume crop (soybeans, moss, beans), which is grown as a secondary crop, enters the legume-forming phase, the increase for bacteria formed at the roots of the plants is further accelerated. It was found that the amount of endogenous bacteria formed in the root of the plant during the soybean formation phase was 9.0-24.6 units/plant. According the results of the experiment, the amount of endogenous bacteria formed in the root of the plant during the legume formation phase of the mung bean grown as a secondary crop was 22.3-36.7 units/plant. During the legume formation phase of soybeans, the amount of endogenous bacteria formed in the plant root was found to be 8.6-22.7 units/plant.

The highest rates of endogenous bacteria formed in the root stage of wild beans grown as a secondary crop after winter wheat were observed in the variant 23, where the norm of mineral fertilizers $\mathrm{N}_{30} \mathrm{R}_{90} \mathrm{~K}_{60} \mathrm{~kg} / \mathrm{ha}$ was applied in the background inoculated with nitrogen before sowing, accounted for 22.7 units/plants. However, In variant 19, where the norm of $\mathrm{N}_{60} \mathrm{R}_{90} \mathrm{~K}_{60} \mathrm{~kg} / \mathrm{ha}$ of background mineral fertilizers sown without inoculation with nitrogen before sowing wild beans seeds was applied, the number of the formed legumes at the root of the plant was 16.8 units/plant. 
Table 1. Norms of mineral fertilizers and the effect of nitragin application on plant root rate, plant/grain (2016).

\begin{tabular}{|c|c|c|c|c|}
\hline \multirow[b]{2}{*}{ 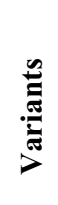 } & \multirow[b]{2}{*}{$\begin{array}{l}\text { Mineral fertilizer standards, } \\
\qquad \text { kg/ha (NPK) }\end{array}$} & \multicolumn{3}{|c|}{ Phases of development } \\
\hline & & $\overbrace{0}^{\infty}$ & 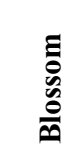 & 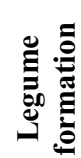 \\
\hline \multicolumn{5}{|c|}{ Soybean (Glycine max L.) } \\
\hline 1 & No minerals & 4.7 & 7.1 & 9.0 \\
\hline 2 & $\mathrm{~N}_{30} \mathrm{P}_{90} \mathrm{~K}_{60}$ & 6.2 & 10.6 & 13.2 \\
\hline 3 & $\mathrm{~N}_{60} \mathrm{P}_{90} \mathrm{~K}_{60}$ & 7.3 & 11.1 & 14.3 \\
\hline 4 & $\mathrm{~N}_{90} \mathrm{P}_{90} \mathrm{~K}_{60}$ & 5.5 & 9.4 & 11.6 \\
\hline 5 & No minerals+ Bradyrhizobium japonicum SB5 & 8.2 & 13.4 & 17.8 \\
\hline 6 & $\mathrm{P}_{90} \mathrm{~K}_{60}+$ Bradyrhizobium japonicum SB5 & 13.1 & 17.8 & 22.1 \\
\hline 7 & $\mathrm{~N}_{30} \mathrm{P}_{90} \mathrm{~K}_{60}+$ Bradyrhizobium japonicum SB5 & 14.8 & 18.9 & 24.6 \\
\hline 8 & $\mathrm{~N}_{60} \mathrm{P}_{90} \mathrm{~K}_{60}+$ Bradyrhizobium japonicum SB5 & 11.6 & 15.0 & 19.8 \\
\hline \multicolumn{5}{|c|}{ Mung bean (Phaseolus aureus L.) } \\
\hline 9 & Without minerals & 11.4 & 18.6 & 22.3 \\
\hline 10 & $\mathrm{~N}_{30} \mathrm{P}_{90} \mathrm{~K}_{60}$ & 14.3 & 22.0 & 26.0 \\
\hline 11 & $\mathrm{~N}_{60} \mathrm{P}_{90} \mathrm{~K}_{60}$ & 16.7 & 25.6 & 29.2 \\
\hline 12 & $\mathrm{~N}_{90} \mathrm{P}_{90} \mathrm{~K}_{60}$ & 13.2 & 19.4 & 25.4 \\
\hline 13 & Without minerals + Phaseolus radiatus 148 & 14.6 & 21.3 & 28.0 \\
\hline 14 & $\mathrm{P}_{90} \mathrm{~K}_{60}+$ Phaseolus radiatus 148 & 18.4 & 26.1 & 33.6 \\
\hline 15 & $\mathrm{~N}_{30} \mathrm{P}_{90} \mathrm{~K}_{60}+$ Phaseolus radiatus 148 & 21.2 & 30.0 & 36.7 \\
\hline 16 & $\mathrm{~N}_{60} \mathrm{P}_{90} \mathrm{~K}_{60}+$ Phaseolus radiatus 148 & 13.8 & 20.8 & 26.2 \\
\hline \multicolumn{5}{|c|}{$\begin{array}{r}\text { Wild bean (Phaseolus) } \\
\end{array}$} \\
\hline 17 & Without minerals & 4.5 & 6.3 & 10.7 \\
\hline 18 & $\mathrm{~N}_{30} \mathrm{P}_{90} \mathrm{~K}_{60}$ & 7.0 & 10.6 & 14.0 \\
\hline 19 & $\mathrm{~N}_{60} \mathrm{P}_{90} \mathrm{~K}_{60}$ & 9.8 & 13.1 & 16.8 \\
\hline 20 & $\mathrm{~N}_{90} \mathrm{P}_{90} \mathrm{~K}_{60}$ & 3.2 & 6.4 & 8.6 \\
\hline 21 & Without minerals + Rhizobium phaseoli 143 & 10.3 & 14.2 & 17.4 \\
\hline 22 & $\mathrm{P}_{90} \mathrm{~K}_{60}+$ Rhizobium phaseoli 143 & 12.4 & 16.6 & 20.7 \\
\hline 23 & $\mathrm{~N}_{30} \mathrm{P}_{90} \mathrm{~K}_{60}+$ Rhizobium phaseoli 143 & 13.0 & 17.8 & 22.7 \\
\hline 24 & $\mathrm{~N}_{60} \mathrm{P}_{90} \mathrm{~K}_{60}+$ Rhizobium phaseoli 143 & 7.5 & 11.0 & 14.3 \\
\hline
\end{tabular}


According to the results, the amount of humus in the $0-30 \mathrm{~cm}$ soil layer of the surveyed fields was $0.725 \%$ in 2016 , total nitrogen content was $0.061 \%$, and total phosphorus content was $0.116 \%$, while in the $30-50 \mathrm{~cm}$ layer these indicators, humus amount was $0.598 \%$, total nitrogen content was $0.053 \%$, total phosphorus content was in the range of $0.099 \%$. The amount of nitrate nitrogen in the topsoil was $3.81 \mathrm{mg} / \mathrm{kg}$, in the subsoil it was $2.26 \mathrm{mg} / \mathrm{kg}$. The amount of mobile phosphorus was $15.2 \mathrm{mg} / \mathrm{kg}$ and $11.8 \mathrm{mg} / \mathrm{kg}$ in the top and sub soil, respectively. The amount of exchangeable potassium was $318 \mathrm{mg} / \mathrm{kg}$ in the 0 $30 \mathrm{~cm}$ layer of soil and $282 \mathrm{mg} / \mathrm{kg}$ in the $30-50 \mathrm{~cm}$ layer. The experimental fields studied were found to be very low and low in nitrogen and phosphorus by typical gray soils classification, and high in exchangeable potassium. Moreover, the norms of mineral fertilizers used in the care of legumes as a secondary crop and nitrogen affected the amount of nutrients in the soil. At the end of the growing season of soybeans, mung bean and wild beans planted as a secondary crop in 2016 , the amount of humus in the soil $(0-30 \mathrm{~cm})$ layer was $0.724 \% 0.723 \%$ and $0.721 \%$ in the fertilizer-free control variants $1,9,17$ of the experiment. They were $0.749 \%, 0.747 \%$ and $0.746 \%$ in the variants 2,10 and 10 , respective, in which the mineral fertilizers at rate of $\mathrm{N}_{30} \mathrm{R}_{90} \mathrm{~K}_{60} \mathrm{~kg} / \mathrm{ha}$ was applied. Overall, there was increased by $0.021-0.024 \%$ compared to the initial values before planting. The amount of humus in the soil was $0.727,0.725$, and $0.723 \%$ in the variants $5,13,21$ without fertilizer, inoculated with nitrogen before sowing the seeds of soybean, mung bean and wild bean crops in the driving $(0-30 \mathrm{~cm})$ layer of soil. When the soil was inoculated with nitrogen at the rate of mineral fertilizers $\mathrm{N}_{30} \mathrm{R}_{90} \mathrm{~K}_{60} \mathrm{~kg} / \mathrm{ha}$ was found to be $0.754 \%$, $0.752 \%, 0.750 \%$ in the variants 7,15 and 23 . Compared to the initial values before sowing, an increase of $0.025-0.029 \%$ in humus was found.

The total nitrogen content was $0.059,0.058,0.057 \%$ in the variants $1,9,17$ without fertilizer control, and $0.063,0.062,0.061 \%$ in variants $2,10,18$, where the norm of mineral fertilizers $\mathrm{N}_{30} \mathrm{R}_{90} \mathrm{~K}_{60} \mathrm{~kg} / \mathrm{ha}$ was applied. Nitrogen content was found to be higher by $0.001-0.002 \%$ than the pre-sowing values. In variants 3, 11, 19, where the norm of mineral fertilizers $\mathrm{N}_{60} \mathrm{R}_{90} \mathrm{~K}_{60} \mathrm{~kg} /$ ha was applied, it was found an increased by $0.006-0.009 \%$ in the nitrogen content when compared to the initial values. Seeds of soybean, mung bean and wild bean crops were inoculated with nitrogen before sowing and the application of mineral fertilizers in different doses, which affected on the total nitrogen content in the soil. The total nitrogen content of the soil was $0.062,0.061$, and $0.059 \%$ in the variants $5,13,21$, treated without fertilizer, inoculated with nitrogen before sowing the seeds of soybean, mung bean and wild bean crops in the drive $(0-30 \mathrm{~cm})$ layer of soil.

\section{Conclusions}

The formation of endogenous bacteria in the roots of legumes, which was inoculated with nitrogen before sowing the seeds of soybeans, mung bean, wild beans that provided a larger yield of 12.0-15.6 units compared to the unused control variants. Excessive use of nitrogen fertilizers leads to a decrease in buds that form on the roots of the plant.

The amount of humus in the $0-30 \mathrm{~cm}$ soil layer of the surveyed fields was $0.725 \%$ in 2016 , total nitrogen content was $0.061 \%$, and total phosphorus content was $0.116 \%$, while in the $30-50 \mathrm{~cm}$ layer these indicators, humus amount was $0.598 \%$, total nitrogen content was $0.053 \%$, total phosphorus content was in the range of $0.099 \%$. The amount of nitrate nitrogen in the topsoil was $3.81 \mathrm{mg} / \mathrm{kg}$, in the subsoil it was $2.26 \mathrm{mg} / \mathrm{kg}$. The amount of mobile phosphorus was $15.2 \mathrm{mg} / \mathrm{kg}$ and $11.8 \mathrm{mg} / \mathrm{kg}$ in the top and sub soil, respectively. The amount of exchangeable potassium was $318 \mathrm{mg} / \mathrm{kg}$ in the $0-30 \mathrm{~cm}$ layer of soil and $282 \mathrm{mg} / \mathrm{kg}$ in the $30-50 \mathrm{~cm}$ layer. 


\section{References}

1. I. Abdumannobovich, J. Nazarovna, U. Khamraqulovna, The American Journal of Agriculture and Biomedical Engineering, 2,12 (2020)

2. R. Juraeva, R., J. Tashpulatov, A. Iminov, X. Bozorov, L. Zaynitdinova, S. Kukanova, Plant cell biotechnology and molecular biology, 21, 61-62 (2020)

3. A. Iminov, S. Hatamov, S. Khayrullaev, The American Journal of Agriculture and Biomedical Engineering. 2, 08 (2020)

4. A. Iminov, A. Kurbonov, S. Khayrullayev, D. Usmonova, International Multidisciplinary Research Journal, 10, 6 (2020)

5. A. Iminov, Sh. Karimov, D. Usmonova, Agricultural and Water Management Agroscientific application of Uzbekistan, 2, 65 (2020)

6. R. Kulmatov, A. Taylakov, S. Khasanov, Environmental Science and Pollution Research, 28(10), 12245-12255 (2021)

7. I. Aslanov, S. Khasanov, Y. Khudaybergenov, M. Groll, Ch. Opp, F. Li, E. Ramirez Del-Valle, In E3S Web of Conferences, 227, 02005 (2021)

8. S. Isaev, S. Khasanov, Y. Ashirov, T. Karabaeva, A. Gofirov, In E3S Web of Conferences, 244, 02012 (2021)

9. Y. Peng, F. Li, N. Xu, R. Kulmatov, K. Gao, G. Wang, Y. Zhang, Y. Qiao, Y. Li, H. Yang, S. Hao, Q. Li, S. Khasanov, Chinese Journal of Eco-Agriculture, 29(2), 312-324 (2021)

10. S. Isaev, S. Khasanov, Y. Ashirov, A. Gofirov, T. Karabaeva, In E3S Web of Conferences, 244, 02047 (2021)

11. N. Sabitova, O. Ruzikulova, I. Aslanov, In E3S Web of Conferences, 227, 03003 (2021)

12. B. Sh. Matyakubov, Z. J. Mamatkulov, R. K. Oymatov, U. N. Komilov, G. E. Eshchanova, InterCarto, InterGIS, 26, 229-239 (2020)

13. K. Marius, K. N'guessan, K. Ignace, K. Kévin, K. Kouassi, Z. Arsène, D. Odette, Open Journal of Soil Science, 10, 6 (2020) 